\title{
Haredi Male Bodies in the Public Sphere: Negotiating with the Religious Text and Secular Israeli Men
}

Yohai Hakak

As a fundamentalist religious group, the Israeli Haredi ${ }^{1}$ community claims to adhere to stable fundamentals of belief which also shape the male body as different from the secular Israeli male body and as opposed to it. In this article I will question such claims by focusing on how young Israeli Haredi men construct their bodies in relation to the secular Israeli body, which is considered their principal 'Other'. I will show that due to the processes the Haredi community is undergoing, and especially the transition of many men from the protected Haredi space to wider Israeli society, the secular body's influence on the Haredi body is increasing in some respects. Other aspects of the Haredi body remain constant and form a challenging alternative to the secular male body. I will also reveal the organizing logic for this process. $^{2}$

In 1999-2000, the Israeli Haredi community was alarmed at the establishment of a new Haredi Brigade (Hanachal Hacharedi) within the Israeli Defense Forces. Until then, young Haredi men did not serve in the army. ${ }^{3}$ The formation of the new unit was received with very vocal protests from all parts of the Haredi community and especially from the more conservative sectors. The common perception of Haredi rabbis of military culture and weapons can be learned from the pamphlet "In the Campaign: Journal of the Torah World", (No. 1 August 1999). This edition is devoted entirely to the "horrors of recruitment" and its terrible implications. The back page of the pamphlet bears a picture of a Haredi child looking admiringly at a Haredi soldier and stretching out his hand to touch the gun he is holding. The picture is captioned: "a pure Haredi child, attending the ceremony at the end of basic military training of the Haredi Nachal unit" [the newly formed unit, Y.H.]. He looks admiringly at the weapons held by the Haredi soldiers. One of the soldiers lowers it and the child strokes the gun longingly, like children who reach out to the Torah scroll when it is removed from the Ark in the synagogue. ${ }^{4}$ The faces (of the child and the soldier in the photograph) are blurred for obvious reasons (ostensibly to preserve their anonymity), and thus readers are saved the expression on this pure child's face when first seeing this 'new world', so opposed to the inner atmosphere of the Torah world. What does the child growing up in an atmosphere of holiness think of this encounter?" 
This short quote illustrates the difficulties that many religious and fundamentalist groups face in attempting to maintain strict adherence to religious positions on all issues, while living in the midst of big, modern and rapidly changing Western cities, surrounded by non-religious majority communities. The Haredi community perceives itself as an alternative to Western culture. Sociologists have described it as a counter-culture (Friedman, 1991) and as an enclave (Sivan, 1991). As part of its attempt to protect itself from outside influences, the community members' bodies are under close surveillance. These bodies are disciplined and controlled according to what is perceived as unchanging religious principles of belief. Every small change in the body's appearance or behavior is perceived as an indication of other, less explicit transgressions, and as a major threat to the community's survival. Since it is also a textual society that lives 'by the book', one would assume that Haredi bodies will indeed reflect these tendencies. In this article I will question such assumptions by focusing on the Haredi male body. I will observe how the Haredi male body is constructed, stressing the points where it conforms to religious dictates and where it transgresses them. This nuanced examination can teach us much about the religious body in other cases where it is constructed in relation to surrounding non-religious bodies.

Current theoretical literature dealing with bodies assumes that they are not innate or essentialist, but the result of social structuring. It further assumes that they are constantly shaped and changed in the course of the interaction between the discourse and the social institutions in which individuals and their bodies function (Ferree, Lorber \& Hess, 1999, p. xvii). The individual and his body adapt themselves to accepted social perceptions, but in parallel they influence them, change them, and are active partners in the process of affirming the identity and the body (Connell, 1995; Frank, 1991).

This literature also indicates that social change at the macro level often leads to change in the body and in male identities at the micro level. One such social change can be the transition of groups of people from one social context to another or the rapid exposure to another competing model of the male body. As I will show, the special social and historical context in which Haredi society finds itself provides such a case. Following Connell (1995), I understand the construction of the male body and identity as occurring in relation to other male bodies and identities. Creating these comparisons is a key means in the struggle for hegemony between the diverse models of the body and of masculinity. On this backdrop, I am interested in the comparisons conducted by Haredi males with other males, and primarily with the secular Israeli males who are their principal 'Other'.

My focus on the relationships between men is in no way intended to marginalize women. It is as much a result of the fact that Haredi men, like men from many other fundamentalist groups, are separated institutionally from women in many aspects of their lives. Therefore, constructing their masculinity is even more dependent on the comparisons they make with other men. Also, as Andrea Cornwall and Nancy Lindisfarne (1994) point out, the ways in which men distinguish themselves and are distinguished from other men must be an important aspect of any study of masculinity.

We should also note that the Haredi body is not essentialized, and that differences with respect to it exist amongst the sub-groups that comprise this 
society, and even between males from the same sub-group, but of different age groups. Yet due to the hegemonic status of the Lithuanian yeshivas and their major influence on yeshivas in other sectors, the similarity between the different sectors, especially regarding the chosen attributes of the male body, is very high. I will only touch on this issue, as it has relatively little impact on the subject under discussion. A similar remark should be made regarding the secular body as perceived by Haredi young men. There is not only one secular male body, and we need to acknowledge its variants. But, in this case, the aspects of the male body which will be discussed here have very similar manifestations and meanings across the secular variations and therefore I will discuss them very briefly. In addition, the Israeli Jewish community is comprised of other groups, such as the modern orthodox (known also as religious Zionism) and traditionalists (Mesorati), which are both religious and modern. These groups, which complicate the dichotomy between Ultra Orthodox and seculars, preferred by Ultra Orthodox, also have a role in the construction of Haredi masculinities. But, due to limitations of space I will not be able to discuss it here.

Although encounters between secular and Haredi males occurred as early as the beginning of the Zionist movement, and increased in intensity after the establishment of the State of Israel, the diverse factors were of limited impact until the last decade. Particularly notable was the Haredi trend to retreat and segregate within the confines of the Yeshiva and the Kollel, ${ }^{5}$ and the protected Haredi space that typified Haredi society in the years following the establishment of the State.

One of the changes that the Haredi sector in Israel has experienced over the last decade is the growing movement from the closed, protected Haredi space to a broad variety of settings in wider Israeli society. Diverse factors contribute to this process, some connected to forces internal to Haredi society and some to external forces originating in wider Israeli society and in Haredi communities abroad. The inner forces include demographic growth and the political strengthening of Haredi society. These trends increase the self-confidence of Haredim and reduce the need to withdraw and segregate as a means of guaranteeing the continuity of the community. To these internal forces should be added the depletion of internal economic resources and the intensification of economic deprivation within Haredi society (Friedman, 1991; Horowitz, 2002; Lupo, 2003). The hardship of Haredi youngsters who are spiritually dissatisfied in the religious seminaries and seek more earthly channels of activity and expression is also a factor (Hakak, 2005). Amongst the external forces is the significant reduction of financial support for large families, Torah students and Torah institutions by the Israeli authorities in recent years. In parallel, the financial support from Haredi communities outside Israel has also diminished. These cutbacks have forced many more male and female Haredim to go out into the labor market. Furthermore, previously the Israeli public sphere was controlled by the great modern secular ideologies, primarily Nationalism/Zionism and Socialism, which posed a threat to Haredi society. The weakening of these ideologies also facilitates the departure of Haredim for the wider Israeli public sphere. This departure does not happen at any specific age, but with regard to males it is more likely to happen after the age of 17 when they move to a high yeshiva where supervision is less strict.

I will examine the complex interactions between religious dictates on the one hand and the pressures of present circumstances on the other, which result from the 
recent increased entry of Haredim into the Israeli public sphere. I will show how the social structuring of the Haredi male body vis-à-vis the secular male body both leads to change and triggers further social change. The encounters between Haredi and secular males also affect non-Haredi males, but these will be discussed elsewhere (Hakak, in progress).

The findings presented here are based on extensive fieldwork that included participatory observations, in-depth interviews and textual analysis and examined the construction of masculine identities and bodies in several key arenas of activity of young Haredi males. ${ }^{6}$ The first was a small Lithuanian ${ }^{7}$ Yeshiva, where the religious authorities attempted to construct the ideal model of the Haredi male body and masculinity. Furthermore, in recent years, significant numbers of young Haredi males entered for the first time many of the other arenas examined here: basic military training, frameworks for professional technological training, and the Haredi headquarters of the Likud party. ${ }^{8}$ These three arenas were all shaped by modern values and perceptions which in many cases contradict those the young Haredi men have internalized through prolonged religious education. Those active in these three 'new' arenas, in contrast to the first arena, the Yeshiva, are mainly young people on the fringes of Haredi society. I will focus here on four main attributes of the Haredi body that appeared repeatedly in these various arenas. These attributes are the control of desires and bodily needs, dress, sport/exercise, and passivity/nonviolence. In each case, I will question how the Haredi body is structured in relation to the secular body, and examine if/what changes were generated by such structuring. I will clarify why some attributes of the Haredi body have remained more stable while others have undergone considerable change. Prior to presenting the findings, I will briefly review research on the subject.

\section{Religious Male Bodies and their Surrounding Societies}

Following the work of Michel Foucault $(1977,1978)$, interest in the research of the body has gained momentum. Amongst those exploring practices and discourses that serve to discipline and control the body in diverse contexts, there are also several which focus on the religious institutional contexts (Coakley, 1997; Mellor \& Shilling, 1997). Discipline and control are examined in these studies with respect to issues such as clothing, the attitude towards corporeal needs and bodily movement (Arthur, 1999; Welland, 2001). This literature is growing continuously and includes a growing range of case studies. Most relate to Christian groups, many of them in the US, and a few to Muslim groups (Ouzgane, 2006) as well as Jewish. There are also many historical analyses, both on Christian as well as on Jewish groups (Boyarin, 1997; Brod, 1988; Cantor, 1995; Gilman, 1991; Satlow, 1996).

A major part of the literature that deals with current fundamentalist groups focuses on their violent characteristics. These are usually interpreted as a response to the encroaching influences of modernity (Aran, Stadler \& Ben-Ari, 2008; Brink \& Mencher, 1996; Krondorfer, 2007; Sered, 1999). In a recent article, Aran, Stadler and Ben-Arie (2008) suggest a different interpretation for expressions of militancy among fundamentalist groups through focusing on male bodies. They interpret physical expressions of militancy as a solution to intra-fundamentalist problems which emerge in advanced stages of the movement's lives. They refer especially to process of institutionalization and routinization that change the inner social relations. While 
focusing on Israeli Ultra Orthodox men they also interpret their militancy as a 'solution' to the 'bodily frustrations and dissatisfactions... rooted as they are in the ascetic lifestyle and stringent rules governing their lives' (p. 26).

Another related issue, seemingly contradictory, that arises from the research literature is that in many contexts, religious men and their bodies are perceived as 'feminine' by the surrounding society. Other parts of the research literature documents the perceptions of religious men themselves describing their religious institutions as too feminine or feminizing (Kirkley, 1996; Krondorfer, 1996; Muesse; 1996; Soucy, 1999). There also appears to be a common tension between the ideal male models held by different religious groups and those held by their surrounding societies. Two main sources for this tension are the commandment to restrain sexuality and restrict it to the marital framework, and the image of subjugation and submission-identified as feminine-expected of the male, relative to the masculine image of God. These tensions are responsible in some cases for men's defection from religious communities (Kirkley, 1996) or for attempts to change their religious communities, rituals or liturgy (Torevell, 1997), and create new and different systems of belief and practice which allow the expression of more muscular masculinities and bodies, such as in the cases of the Promise Keepers and GodMen. According to Krondorfer (2007) these tensions became stronger in modernity:

In modernity... traditional-religious models went out of fashion, among other reasons because respect, power and authority were increasingly found in the secular realm rather than in ecclesiastic contexts. Religious matters were assigned to the private sphere. With the awakening of the idea of nation states, with colonial expansionism and a seemingly unstoppable technical progress, more "manly" (i.e. more belligerent, national and heroic) ideals of masculinity were needed. Religious sentimentality was considered to be something private, soft or even neurotic (as reflected in the thoughts of people ranging from Friedrich Nietzsche to the American pragmatic Williams James). In modernity, repeated attempts were made to re-masculinize church life. "Where are the men in church?" is, therefore, a modern question. (Krondorfer, 2007)

Zionist activists in the late nineteenth and early twentieth century have expressed similar opinions about traditional Judaism, describing its males and their bodies as highly feminine (Boyarin, 1997; Gluzman, 1997; Nordau, 1902). They declared that in order to make the Jewish people a 'nation like all nations' there is also a need to create a New Jewish male which will cast away all the exilic remains and will acquire a new manly and heroic masculinity. The Ultra Orthodox community did not take that path and continued to adhere to the traditional religious models. Shortly after the establishment of the State of Israel, yeshiva studies became the only normative path for every Ultra Orthodox young man. Under the shelter of these total institutions was constructed an ideal male model, with many of its attributes identified in western culture as feminine. He is expected to be gentle in his body; his skin, pale from not being exposed to the sun due to his intense religious studies; his back hunched from leaning over his books. He is expected to avoid violent confrontations with other men, to limit his sexuality to marital relations and subdue himself to the will of God. Still, these yeshivas grew and spread at a very fast rate as 
well as the number of men within them. This tremendous growth was happening while totally different and even contradictory masculine ideals were dominant in the surrounding Israeli society.

\section{Jewish, Israeli and Haredi Bodies}

Before commencing, I will review briefly some of the findings in the literature on the Jewish body, which historically received remarkably little attention. Eilberg-Schwartz (1990, 1992) shows how, in response to the Eurocentric western research on religions which identified certain religions as wild and primitive, Jewish researchers made an effort to downplay most corporeal aspects of Judaism that might be interpreted in this manner. At the same time, great effort was invested in describing the Jewish religion as rational. He maintains that this is one of the reasons for many Jews' adoption of the moniker attached to the Jewish nation-The People of the Book. For the same reasons, and since anthropology formerly focused traditionally on 'primitive' societies and dealt quite considerably with the body, few interpreters of Judaism deigned to address this discipline when in search of a theoretical framework or real insights. These also had far-reaching implications for the questions researchers tended to ask, the comparisons they tried to make and the research tools they typically used. All these contributed to distancing researchers of Judaism from the subject of the Jewish body.

Most of the existing studies on the Jewish body are based on textual analysis, focusing on the connection between changes in historical circumstances and the attributes of the Jewish male body (Boyarin, 1997, 1999; Cantor, 1995; EilbergSchwartz, 1992; Gilman, 1991; Jacob, 1997). Some of the general trends described by these studies are presented below. The reality clearly also embraces out-of-theordinary situations.

The Jewish attitude towards the body has apparently always been ambivalent, and almost from the outset, has shown considerable concern regarding its supervision and restraint (Eilberg-Schwartz, 1992). Judaism prohibits monasticism, in contrast to the main streams in Christianity and in several other religions, and the body remains an essential factor on the path to God. The complex objective is sanctifying the body, reducing its earthliness and making it spiritual, mainly through meticulous discipline of the body, harnessing to spiritual goals and self-transcendence. The individual is committed to commandments such as "be fruitful and multiply", which can only be carried out through the body. But at the same time, the dominant perception is that man is created in God's "image and likeness", motivating him to rid himself of his earthliness and emulate the Lord's spirituality.

The attitude of Judaism towards the body changed significantly after the destruction of the Second Temple (in $70 \mathrm{CE}$ ) and the exile that accompanied it. Due to circumstances in the Diaspora and the lack of feasibility of working the land and carrying weapons, definitions pertaining to the body, heroism and masculinity changed. Previously, Judaism emphasized bodily control and discipline and did not hold military might in particular esteem. ${ }^{9}$ Thereafter, we witness an intensification of the tendency to see those who control their urges and earthly lusts and subordinate them to the heavenly logic embodied in God's commandments as heroes and ideal men (Boyarin, 1997; More \& Anderson, 1998; Satlow, 1996). The hero is not the 
conqueror of fortresses and vanquisher of enemies, but "he who conquers his passions", particularly as expressed through the study of Torah. Thus, we find expressions such as "a Torah hero", the "Torah's battle" and the student as one who "kills himself in the tent of the Torah". ${ }^{10}$

Bodily restraint is perceived as a condition for the flourishing of spiritual life, an objective that can best be achieved through the study of the Torah and, mainly, the Talmud. These tendencies gained further strength in the Middle Ages under the influence of Hellenistic trends that identified femininity with the body and with earthliness (Boyarin, 1993), and intensified further with the appearance of Hassidism and the Mussar movement in the eighteenth and the nineteenth centuries. In this framework, the belief that the body is the domicile of the evil inclination and the potential dwelling of impurity strengthened (Etkes, 1982; Katz, 1970, 1996). The Mussar movement, sectors of which brought physical self-mortification to new heights, admittedly disappeared as an independent factor, but did leave a clear stamp on the world of the Lithuanian Yeshivas. The Volozhin Yeshiva, for example, was an exemplary case of the modeling of the yeshiva as a total institution (Goffman, 1961). With the arrival of this model in Israel and its adaptation to become the main instrument of separating between Haredi youth and their non-Haredi environment, these approaches were reinforced. ${ }^{11}$

Haredi society tries to preserve these tendencies and perceptions in the reality of life within broader Israeli society, in which totally different and sometimes contradictory attitudes regarding the body are common. These attempts require a great investment of energy. They have created a whole new, modern reality, compared to the years during which these perceptions were passed relatively effortlessly by tradition from father to son (Brown, 2006). Under the influence of European nationalist movements that adopted and revived the Hellenistic body culture (Leoussi \& Aberbach, 2002), the heads of the Zionist movement expressed similar fears to those mentioned above as to the femininity of the traditional Jewish male body. They aspired to shape a new generation of Jewish men who would be modern and secular, with athletic and muscular physiques. These men would be different from the Diaspora Jew, characterized by his traditional and religious Jewish awareness and weak 'female' body (Boyarin, 1997; Gluzman, 1997; Nordau, 1902; Shorek, 2002). Assertive behavior, manifested in diverse ways, including the national and military levels, accompanied the new Jewish body. Haredi rabbis saw the establishment of the State of Israel as a manifestation of this masculine antitraditional assertiveness, some deeming it to be a great $\sin .^{12}$

With the establishment of the State of Israel, the "Tzabar generation" (Almog, 1997) adopted the attributes of the Zionist body. The body of the new Jewish male was supposed to be tall, muscular through exercise and tanned from physical labor under the hot sun; the Jewish male was supposed to be assertive and self-confident. This ideal male model is still a symbol and paradigm for most Jewish Israeli males, particularly in view of the centrality of military service in Israeli society (Ben-Ari \& Dardashti, 2001; Kaplan, 1999; Lomsky-Feder \& Rapaport, 2003; SassonLevi, 2006; Sion, 1997; Weiss, 2002).

Modern Israeli society is also exposed to the Western discourse of later permissive capitalism that encourages consumption. In this secular discourse, physical needs and passions are not only condoned, but encouraged. The body in 
this discourse is highly controlled and disciplined, but this time in an attempt to make it an object of greater passion (Turner, 1996, p. 23).The Ultra Orthodox community resisted these varied influences and continued its attempts to adhere to the traditional religious models.

Several studies have explored the Haredi body, focusing mainly on the female Haredi body, whether in Israel (Finkelstein, 1997; Oryan, 1994) or in the USA (Goldman, 1999). Much of this research is focused on the educational attempt to discipline and control women's bodies and sexuality, starting from the kindergarten (Yaffe, 2004) through school years (Oryan, 1994) and the preparation towards marriage (Finkelstein, 1997). Other research examines dress as reflecting intracommunity status (Goldman, 1999).

Studies on the Haredi male body in current times are fewer and they rarely discuss the construction of the Haredi body in relation to the secular body. Blumen (2007) focused on the bodily performance of going to (unpaid religious) work in an Ultra Orthodox neighborhood bordering a major secular town. She described both ultra Orthodox men and women as challenging the capitalist bodily performance of going to work and the decree to participate in the labor market and have a paid job. Bilu (2000) explores the psycho-cultural meaning of corporal ceremonies such as circumcision, the first haircut at age three and the first entry to the cheder-a traditional training in basic religious literacy. The first two ceremonies share the removal of parts of the body identified as female (the foreskin in circumcision and long hair in the first hair cut), en route to creating the desired body and male identity. This study seems to stem from the assumption (not shared in this article) that beyond all cultural aspects there is a deep male identity structure, preserved throughout history and in diverse cultures. ${ }^{13}$ Examining the Haredi body through analysis of the meaning and effect of the ceremonies contributes to understanding the construction of the hegemonic body and masculinity in this society. It also affords a basis for understanding the subversion and resistance to the hegemonic model discussed in this article. Aran (2003, p. 121), in mapping the diverse aspects of the Haredi body, highlights its attempt to avoid extreme physical situations, such as absolute relaxation or the maximum strengthening of the physique, typical of the secular body. These two contradictory situations are perceived as devotion to the body and hence, he maintains, are rejected by the Haredi world.

In this article, I intend to show how, through the encounter with the secular body, Haredi reservations with respect to these physical situations are shaken. At least two of the four attributes of the Haredi body on which I have chosen to focus are connected to those extreme physical situations to which the Haredi body is traditionally averse. Needless to say, of course, the four attributes do not purport to encompass all aspects of the Haredi body and were chosen for a variety of reasons: their centrality to the ideal model of the Jewish male body, their distinctiveness and difference from the male models in relation to which they are constructed, their contribution to the claim that I attempt to develop here, and the ease of my access to relevant findings.

\section{Freedom from Bodily Demands or Submission to them}

A central aspect of the body in Haredi thinking is the attitude towards bodily needs, urges, desires and wishes. While western culture, under the influence of 
psychological and consumer discourse, encourages the expression and satisfaction of various physical needs, and emphasizes their legitimacy and even their essentiality for the individual's mental health, the attitude of Haredi society to corporeal needs and urges is totally different. The topic arose in many interviews I conducted with Haredi youth. As Avraham, ${ }^{14}$ one of the Yeshiva students I interviewed, states:

"I often find it hard to get up for prayers, but eventually I manage ....and get up...Because that's what I'm supposed to do. People say the Haredim are poor sods - they are closed, and forced to do this and that. I think it's the exact opposite. The Haredim are the only people who are free of everything. Why? Because no one can force me now to go and steal. Why? Because I will overcome my urge, I won't do it. I hear that they call secular people free; I don't understand why... because...if the evil inclination obliges you to go now and watch football-you'll go; you are like in a prison ....and that's what the Talmud actually says: There are no free men apart from those who are involved in learning Torah".

Such claims were repeated in diverse contexts. Secular Israeli males from different ethnic backgrounds were perceived as over legitimizing their bodily urges. Here, Avraham repeats the Haredi criticism of modern freedom, ${ }^{15}$ i.e., the freedom of the secular person who is not committed to Halacha (religious Jewish law) enslaves him to his proclivities. Real freedom-from the rule of the inclinations and passions-is only facilitated by a Haredi lifestyle. This lifestyle forces the individual to do two things: first, to 'overcome ${ }^{16}$ his appetites; second, to observe the commandmentsand for men primarily, the command to be immersed in the study of the Torah. ${ }^{17}$

The ability to control and restrain the body is described as a key resource by many interviewees. However, it seems that recent years have seen some attrition in the degree of restraint and control applied to bodily needs. Two main sources for this are the psychological and consumer discourses that infiltrate Haredi society and grant greater legitimacy to individual needs, including bodily needs. At the same time, this attribute, more than any other of the Haredi body, seems to have undergone relatively few changes. It may be possible to explain the endurance of this attribute by its continued usefulness in helping these youngsters adapt to the demands of the wider Israeli society that they encounter. Evidence for this is provided by the comments of Rabbi Meir Tessler, one of the heads of the Haredi Center for Technological Studies, to one of the Center's graduates: "Rest is for the world to come. Here we work" (quoted in Hakak, 2004, p. 83). Rabbi Tessler refers to the Jewish vision of the Garden of Eden in the World to Come, as a place where the hardships and difficulties of survival in this world do not exist; yet one should work and exert oneself in this world in order to reach it. In this case, however, the effort demanded by Rabbi Tessler is not the performance of God's work, as is customary in Jewish perception, but work in the world of hi-technology.

The restrained and carefully controlled body was most typical in the early stages of capitalism, as it helped increase production (Turner, 1996). Turner shows how the need to increase consumption at home was first created as a result of the shrinking of America's external markets. Consequently, the dominant ascetic discourse changed gradually to one granting greater legitimacy to diverse needs. The 
world of work, however, continued to demand the ability to delay gratification and to discipline and control the body. Emphasizing the control of bodily needs fulfills a similar role for the Haredi sector that encounters Israeli society and seeks, amongst other things, to integrate into a competitive and achievement-oriented labor market that demands delaying gratification and a high level of discipline. In view of the considerable gaps in secular studies with which most Haredi males arrive at the labor market (Hakak, 2004), the ability to control corporeal needs and delay satisfaction is of double importance. Many of the interviewees also expressed the view that the Haredi way of life and its many religious demands preclude laziness and make Haredi people more disciplined and hard-working than people from other sectors.

\section{The Body as a Site of Individual or Collective Expression}

Another central aspect of Haredi involvement with the body focuses on presenting the body in public and, particularly, through the mode of dress. While Western culture, influenced by consumer culture, stresses dress and personal presentation in public as a central site for self-expression and self-realization, in Haredi society, dress manifests the commitment of the individual to God and the community. ${ }^{18}$ The distinctive and uniform dress, alongside other external attributes such as side-locks and a beard, are designed to distinguish the Haredi male from his non-Haredi surroundings and prevent him from perhaps being swallowed up and affected by them.

Torah students are reminded that they are perceived by others as representing G-d and his word, and are thus obliged to be careful in their behavior and appearance, especially in the public sphere. Many quoted the passage of the Talmud, stating that "a sage with a stain on his clothes merits death" (Babylonian Talmud, Tractate Shabat, 114: 71) for me. While all Yeshiva students strive to maintain respectability, yeshivas can be classified according to the degree of restraint, control and self-denial required of their students. This will also determine, amongst other things, the degree of openness to the changing styles of dress. ${ }^{19}$ In discussions with yeshiva students and Haredi young activists at the Likud Party, the mode of dress of their secular cohorts was described as having two main attributes. The first is its accentuated material and earthly character. This is contrasted with the Haredi attempt to restrict these aspects, for example, by wearing delicate shoes rather than high boots with a heavy sole, as habitually worn by secular youth, especially those nearing recruitment age or following discharge. The second is that while the mode of secular dress is intended to emphasize difference, uniqueness and deviation from the norm, ${ }^{20}$ this is seen by Haredi young men as eccentric and bizarre, and arouses distance and contempt. Especially contemptible were the Punks. On the other hand, the interviewees with whom I spoke also described the criticism levied at them by secular youth regarding their black and impersonal dress. Most did not try to refute this description, but replied with the counter-criticism, that while secular youth is occupied with creating impressions and is prepared to dress in a strange and surprising manner in order to be special, we, the Haredi youth, dress in a respectable manner. In order to illustrate this respectability, the high costs of the items of Haredi dress were described to me, compared to the low cost, they believed, of the secular items of dress. Apparently, in light of the frequent ventures of Haredi youth into the wider Israeli space and their many encounters with non- 
Haredi youth, and given their need to counter the secular criticism of their uniform dress, Haredi youth today insist on their greater respectability and prestige; this provides some compensation for the drawbacks of its impersonal character.

The call to preserve the uniform but respectable appearance is well exploited by advertisers working in the Haredi sector. There, the male clothing market has become very active, especially over the last decade, where it has been exposed to the impact of changing fashion. While Haredi dress is supposed to reflect respectability, simplicity and modesty, the pressures described here and the close encounters with secularity and with the consumer culture have considerably eroded the value of simplicity and its manifestation in dress. ${ }^{21}$ The simple suits worn by Yeshiva students until a decade ago are now modern and almost completely identical to the suits worn by businessmen or managers in the modern labor market.

Another factor that reinforces the impact of current western dress is the recent growth in the number of Haredi men who go to work. Under cover of this process, another consensus was created, according to which many Haredi men who go out into the labor market exchange the yeshiva-style white buttoned shirt, identified as the 'uniform' of Torah students and Haredi men in general, for a colorful buttoned shirt, thus increasing their resemblance to the modern businessmen. The legitimization of the colored buttoned shirt sketches, in fact, an alternative physical model that is fairly similar to the yeshiva model. Like the 'yeshiva body', a body enclosed in a business suit and buttoned shirt is restrained, meticulous and under control. The buttoned shirt is, in fact, part of 'power dressing', the male dress common amongst businessmen or managers, which serves as armor against penetrating the body and as a barrier to the flight of diverse bodily materials. Such dress makes it difficult to identify the outline of the body, and in this sense, it obscures the gaze. The straight and sharp lines of both the buttoned shirt and of the suit disguise the body's curves as well as its physical and sensual essence, and are intended to reflect control, power, rationality and masculinity (Longhurst, 2001). The change made by many Haredi youth in their dress enables them, on the one hand, greater access to the non-Haredi Israeli space, while preserving most of the attributes of uniform Haredi dress and stressing conformity to community values. Furthermore, in my interviews, Haredi youngsters in all arenas, but especially in the Likud Party and the occupational training program, described the sense of belonging to a community, as symbolized by uniform and impersonal dress, as the key advantage over their non-Haredi cohorts, since that community provides a network of aid, support and useful connections. Consequently, few forego the uniform dress. In this respect, they did not conform but challenged and created an alternative to the male bodies in the surrounding Israeli society. This alternative, of being part of a close and committed community, as symbolized by the uniform dress, is portrayed in wider Israeli media in recent years in very positive terms and with some envy due to its economic and political benefits. ${ }^{22}$

\section{The Culture of the Body or the Culture of the Spirit}

Another key attribute of the Haredi body is connected to practices and involvements considered appropriate. Since the body supports the soul and is the tool through which the Creator's work is performed, it must be maintained and nurtured as well as possible. At the same time, the hierarchy between the body and the soul is clear, 
the final purpose being the wholeness and functioning of the soul and its imposition on the bestial and earthly body. Given the approach that sees the body as only a vessel for the soul, there is no reason to develop it for its own sake through what is known as the 'body culture'. Hence, there is no sports equipment in Israeli yeshivas; there are no sports lessons, and no time is allocated to physical activity. ${ }^{23}$ The Haredi newspapers also ignore the subject, except for reports of a mass scuffle on the football field as evidence of the secular bestiality of Hellenism. ${ }^{24}$

Limited physical activity is likely to enjoy partial legitimacy as long as it is perceived as helping to increase learning ability. Several rabbis $^{25}$ have already expressed support for physical activity for yeshiva students as an outlet for their excess energy and as an aid towards overcoming their inclinations. But this is usually an area that belongs to 'gentile customs' and, more specifically, to Greek culture, ${ }^{26}$ and the attitude towards it, whether on the part of the Rabbis or on the part of the community is still hesitant and suspicious. Involvement with sports arouses great resistance, especially when its purpose is to become more professional, more sophisticated and achievement-oriented, and facilitate participation in competitions. Passive involvement in sports culture, i.e. admiring sports stars and watching competitions, also arouses great reservations. Instead of sports, the youth are expected to expend their energy by dancing at weddings; consequently, attending weddings has become particularly frequent.

The social conventions described here also have a tremendous impact on how young Haredi men perceive their bodies in comparison with the secular body they encounter. This topic was mentioned in many interviews carried out. The discussion of the physical skills of the Haredi body became central, particularly in basic military training, where I conducted fieldwork. In this setting, as well as in the other research settings, the Haredi body was described repeatedly as far weaker and even shorter (!) compared to the bodies of young secular men. This was usually explained by the lack of Haredi involvement in sports. Just as involvement in the Torah was described as shaping the body, intelligence and behavior of the student of the Torah, participating in sports was described as shaping the bodies of secular people. These descriptions were accompanied by some expressions of envy.

In spite of the determined misgivings of the rabbis, various branches of sports have gradually become more popular and the number of Haredim and Yeshiva students actually practicing sports, as well as the number of those interested in them as spectators or as supporters, has increased over the years. In this case too, the growing frequency of encounters with secular males plays a key role, but to these are added the increasing influences of the medical discourse and the mounting concern over the 'quality of life' in Haredi society. Evidence of escalating involvement in sports are many, starting from the growing number of gyms opening in Haredi areas ${ }^{27}$ to the increase in the number of Haredi football supporters ${ }^{28}$ and of those learning martial arts of various types. As in other areas, some of the main agents of change responsible for this trend are Haredim from abroad ${ }^{29}$ and the newly religious. They bring with them from the 'outside' world physical skills and traditions that are hard to change; furthermore, there is a demand for them within the Haredi community. The medical discourse often affords legitimacy to increased involvement in sports, and the common use of the terms 'health exercise' and 'health center' in the Haredi sector in recent years is evidence of this. I will quote 
here comments made by a yeshiva student in explaining his participation in Taekwondo (martial art) lessons, in spite of the displeasure of the rabbis of the Yeshiva in which he studied:

"Personally, I simply need it to relieve tension. There are many hyperactive guys like myself, who must find relief when they sit and learn, and simply can't manage without it".

Haredi rabbis who oppose drafting yeshiva youth to the Israeli army maintain there is a division of labor between Haredi society and the other Jews in Israel. Haredi society guarantees the spiritual existence of the nation via the study of the Torah, while the other Jews in Israel are responsible for the material aspects. But this division of labor is questioned the moment yeshiva students, who are responsible for spiritual aspects according to Haredi belief, also wish to take a greater part in material life. The Haredi rabbis voice their objections, but to no avail.

\section{Passivity as an Ideal that is Passé}

The last attribute which I will refer to is connected to the attitude of the Haredi body to other bodies. Boyarin (1997) claims that the Talmud encouraged creating a 'female' man who does not fear weakness as a key component of his personality, and that this approach greatly influenced Jewish life throughout history since the finalization of the text of the Babylonian Talmud in 500 CE. Refraining from violence and belligerence, especially in the physical sense, is still typical of Haredi society. ${ }^{30}$

The changes with respect to this attribute of the body and of Haredi male behavior are even greater if compared to the other attributes mentioned here. Processes of change and the introduction of assertive male models into male Haredi society were particularly prominent during basic military training, where some of the fieldwork for this research was conducted. As a rule, Ultra Orthodox men are not drafted to the Israeli Defense Force. They comprise a legal category of those for whom 'Torah studies is their sole craft' (in Hebrew: Toratam omanutam). Those who do get drafted, like the cadets I have researched, are very few. Usually they are among the less successful yeshiva students. The cadets I observed were going through a very basic and short training of four weeks and were not meant to be part of the fighting forces. After this training they were positioned as teacher-soldiers within Ultra Orthodox schools and as part of the Education Corps.

At the beginning of the basic training, and in reaction to the rigid disciplinary efforts of the base staff, the recruits employed traditional Jewish practices to attain power, primarily unity against adversity (Biale, 1980), with remarkable speed, especially given their lack of previous familiarity with each other. A few days after starting basic training, the recruits reacted to the disciplinary efforts and the staff's demands with passive oppositional practices customary in the yeshiva world, such as fasting or refusing to perform certain tasks. These types of action changed rapidly in the course of military training.

If military service is seen as a transition ceremony to masculinity, strewn with a series of tests (Ben-Ari \& Dardashti, 2001), the ultimate test will be, one may assume, participation in battle. But since in every army, including the Israel Defense Forces, only few soldiers actually participate in the battle (including those in combat 
units), the military system provides mock battles as an alternative, with shooting practice as a main activity. A soldier who successfully handles these simulations under the critical eye of his friends and officers, also becomes a 'man'.

Participation in shooting practice began with much concern and excitement prior to the event, and concluded with tremendous, almost ecstatic joy, especially amongst those who felt they successfully passed the test. In interviews I held after the conclusion of the basic training, many recruits mentioned shooting range practice as one of the peak moments. At least some of them felt that this experience would alter them for the rest of their lives. Ya'acov, one of the recruits, described it thus:

"I believe that the moment you know how to hold a weapon and can react to those attacking you, something changes. You aren't helpless. For example, already in the first week, after one shooting practice, they told us to guard the base. Although we didn't really know how to shoot or to hold a gun, we guarded the base; even if we hadn't quite scored a hit they knew we would react... And this is important for life afterwards, even when you walk along the road without a weapon-you already feel different".

At least for some of the Haredi recruits, the successful completion of the shooting range increased their self-confidence and the feeling they can 'react', even outside the framework of basic training. Several of the cadets, for whom the experience was especially positive, expressed envy towards other non Haredi units which were going through much longer and strenuous basic training in the same base. 'We too should have been Rambo for a while', said Elimelech.

The successful passing of the shooting range may also contribute to the increased tensions in their relations with the base staff, as the basic training drew to an end. These tensions reached the point of frontal confrontation in the final days. During the summary session with the base commander, the recruits made levied accusations, especially with respect to their officers. Later, they even adopted some of the language and practices used by the staff, including talking about 'opening a distance ${ }^{31}$ from their officers, for which they employed accessories such as peaked cloth caps and dark sunglasses. These two accessories are meant to block the gaze from the outside and are used usually only by the staff as a means of distinguishing themselves from their trainees.

While Haredi rabbis and educators following traditional Judaism prefer avoiding conflictual situations when they might possibly result in desecration of God's name, the Haredi recruits are not prepared to exercise self-restraint and prefer to retaliate and insist on their honor. This demand for honor and for 'opening distance' undoubtedly reflects the adoption of patterns of their officers' assertive male behavior, while adapting its terminology to their needs. Tuvia, one of the recruits, tried to explain his friends' behavior:

"We were once a small group which sought to protect itself ...we are now a society that does not need to protect itself any more because we have...political...financial, communal power... We help people to become religious, the Haredi political parties are growing...We no longer go to the 
(Polish) landowner to ask for money.... Now we decide when and if to give money [to others]..." 32

Tuvia links his friends' behavior and self-confidence to the demographic and political growth of Haredi society. This is no longer a Jewish community at the mercy of the non-Jewish landowner, but a Jewish community in the Jewish state that enjoys a preferred status compared to other non-Jewish communities. Furthermore, due to its political strength, it has not only petitioner status, but already enjoys the status of benefactor. All these also filter into the feelings of individuals and are manifested in their behavior and body. The community's political influence and its tensed relations with the army are some of the reasons for the staff's extreme tolerance towards the cadets' rebelliousness. Further evidence of increasing self-confidence surfaces from the description of another yeshiva student, Eliyahu, regarding the meeting between one of his acquaintances, described as the neighborhood thug, with secular youngsters at a Jerusalem shopping mall:

"Some guy with a leather shirt came up...trying to prove he's some sort of toughie and he laughed at religious people, and cursed them saying [that]...all the religious girls are whores... And that Shlomo... He's no sucker....And when someone offends him, he gets hurt...They began to argue...it came to blows and Shlomo bashed him up, simply ripped him to pieces...yeshiva students react more nowadays 'cos we feel we are hated. We aren't afraid either...the silence is over... The Haredi public already feels...(that) being a sucker is in the past...(now) if someone starts with us we'll show him. There are no more suckers."

Eliyahu displays his great anger, his lack of desire to restrain himself and his self-confidence that enables him to do this more often than in the past. Eliyahu and Shlomo live in a Jewish state where Haredi members of the Knesset (Parliament) and Haredi government ministers hold many powerful positions and the attitude of the authorities toward them is totally different. Young Haredi people have fewer reasons to fear forbearance when they are attacked or when they feel they are 'suckers'.

Eliyahu says, in fact, that he and his friends do not intend to restrain themselves if others display arrogance towards them, belittle them or insult them. They feel strong enough to stop waiving their honor, and convert the insult into a motivating force for action. The use made by Eliyahu of vernacular, secular Hebrew, and the many expressions that describe macho and assertive masculinity, is also prominent. Under present social circumstances and despite the rabbis' ongoing doubts, ${ }^{33}$ the manifestations of this new assertive-active male model are increasing. The encounter with the modern, competitive world in which assertiveness and determination are values, is likely to amplify these tendencies. It is possible to assume that these manifestations of masculinity are adjusted to specific situations. In some cases, especially when entering the Israeli public sphere, they might have a strategic value, but on other occasions within the Haredi community, they might be less useful or even unacceptable. 


\section{Dangerous Encounters: Summary and Comments}

Like many other fundamentalist groups, the Ultra Orthodox community maintains a sharp tension between its rhetoric, which states strict adherence to religious fundamentals, and the changing reality. If one accepts this religious rhetoric uncritically one would expect male identities to be unchanging through time and totally complying with the unchanging religious text. But as I show here, such an expectation would ignore the influence that social forces have, in addition to the religious text, in molding religious masculinities at a specific time and place.

As described in the literature review, in many contexts, religious men and their bodies are perceived as 'feminine' by the surrounding society or by describing themselves and their religious institutions as too feminine or feminizing (Soucy, 1999; Kirkley, 1996; Krondorfer, 1996; Muesse, 1996). Most research is on Christian men, but also on Jewish and other men. The research material brought here only partially repeats this pattern. The descriptions of secular males by young Haredi males, as presented here, are rather critical. The latter were largely described as servile and controlled by their urges, as libidinous, self-interested, lacking in values, materialistic, loud, extrovert, arrogant, empty, superficial and aggressive. To link with these perceptions, when moving into wider Israeli space, some aspects of the Haredi men's bodies form a challenging alternative to other Israeli male bodies. They stress, in particular, the restraint of the body and of inner urges in the spirit of "who is a hero-he who conquers his passions", in contrast to the considerable legitimacy afforded to satisfying needs and desires, as is commonly accepted in secular Western society. They also stress their notable commitment to the community-again, in contrast to the secular Western ethos which places the individual at the center. These attributes of the body and of Haredi masculinity would also seem to provide a resource in the exodus towards integration within the wider Israeli society; hence, they are retained. The fact that in Israel, state and church are not separated by law, and religion is not limited to the private sphere, might be part of the explanation for the difference in comparison with other modern Christian groups and for the ability of Ultra Orthodox men's bodies to form such a challenging viable alternative.

But along with these aspects and the accompanying criticism, ridicule and contempt toward the secular bodies, one can also sense a not-insignificant element of envy, appreciation and amazement, even if their presence is more covert. A large part of that amazement and even envy is focused on the secular male body that is perceived as far more developed, taller and stronger than the Haredi physique. The non-Haredi Israeli male is perceived as capable of defending himself, his honor and his family with his body; he is familiar with his wider surroundings, does not fear nature, and has the ability to influence and mold them to his wishes.

In contrast, when entering the wider Israeli space, Haredi masculinity and bodies are seen as 'defective' and many of its characteristics are perceived as 'female'. Its forbearance, passivity and undeveloped 'female' corporeality, are harder to maintain as an alternative. In Israeli society following Jewish exilic experience and the horrors of the Holocaust, these attributes are bearing a considerable negative charge. Furthermore, the continued Arab-Israeli military struggle reinforces assertive-masculine attributes, while the competitive capitalist economy only furthers this tendency. Hence the encounter of Haredi men with other Israeli males arouses fear, especially during the formative period of adolescence, when male 
physical identity is molded through heightened exploration. It would seem that in the struggle for hegemony between male models (Connell, 1995) and in order to claim their place relative to direct, assertive Israeli masculinity, Haredi males are forced to adopt attributes of a more assertive body and masculinity.

As presented earlier, similar interpretation served several scholars describing mainly Christian groups but also Jewish ones (Eilberg-Schwartz, 1996). The departure for the material arenas described here and the experience of a corporeality and masculinity more closely connected to the earthly world, the world of action, enable young Haredi males to experience new dimensions of the body and masculinity and reduce their fears. This would also explain the attempts to undermine the ideal Haredi model, still held by the religious authorities, make it more flexible, expand it and remold it. It also explains the tremendous enthusiasm expressed by Haredi military recruits upon firing a gun in shooting practice, and what sometimes seems to be exaggerated Haredi excitement after 'action' when volunteering for organizations such as the Israeli emergency medical services. The prevalent image of fundamentalist men in many cultures as feminine could also explain fundamentalist violence and militancy as a form of reaction or compensation related to this image.

Following this research it would be interesting to learn how religious male bodies are constructed in other social contexts, and what are the conditions that allow them to create an alternative to secular and other male bodies and what, on the other hand, are the conditions that minimize and limit such a possibility.

\section{References}

Aran, G. (2003). The Haredi body: Chapters from ethnography in preparation. In K. Kaplan \& E. Sivan (Eds.), Israeli Haredim: Integration without assimilation? (pp: 99-133). Jerusalem: Van Leer Institute and Hakibbutz Hameuchad Publishing House. (Hebrew).

Aran, G., Stadler, N., \& Ben-Ari, E. (2008). Fundamentalism and the masculine body: The case of Jewish ultra orthodox men in Israel. Religion, 38: 25-53.

Arend, A. (2002). The body and sport culture in recent generations. In H. Kaufman \& H. Harif (Eds.), The body culture and sport in the twentieth century, pp. 25-50. Jerusalem: Yad Ben Zvi Publishing. (Hebrew).

Arthur, L. B. (Ed.). (1999). Religion, dress and the body. Oxford: Berg Publishing.

Baharan, A. (1990). Society and its influence according to the stance of our sages of blessed memory and the great scholars. Jerusalem: Hamesorah. (Hebrew).

Ben-Ari, E. \&, Dardashti, G. (2001). Tests of soldierhood, trials of manhood: Military service and male ideals in Israel. In D. Maman, Z. Rosenhek \& E. Ben-Ari (Eds.), Military, state and society in Israel: Theoretical and comparative perspectives, pp. 239-269. New Brunswick, NJ: Transaction Publishers.

Bilu, Yoram (2000) From circumcision to circumcision: A psycho-cultural analysis of male identity construction in childhood ceremonies within the Haredi community. Alpayim, 19: 16-46. (Hebrew).

Blumen, O. (2007). The performative landscape of going to work: On the edge of a Jewish ultra orthodox neighbourhood. Society and Space, 25: 803-831.

Boyarin, D. (1997). Unheroic conduct: The rise of heterosexuality and the invention of the Jewish man. Berkeley, CA: University of California Press. 
Boyarin, D. (1993). Carnal Israel: Reading sex in Talmudic culture. Berkeley, CA: University of California Press.

Breuer, M. (2004). The tents of Torah: The Yeshiva, its structure and history. Jerusalem: Zalman Shazar Center for Jewish History. (Hebrew).

Brink, J., \& Mencher, J. (1996). Mixed blessings: Gender and religious fundamentalism cross culturally. London: Routledge.

Brod, H. (1988). A mensch among men: Explorations in Jewish masculinity. Freedom, CA: Crossing Press.

Brown, B. (1999). Real desire or the evil urge: The Haredi perspective of two Haredi thinkers. Philosophy in Jewish Education, I: 98-125. (Hebrew).

Brown, B. (2006). The range of orthodox responses: Ashkenazim and Sephardim. In A. Ravitzky (Ed.), Shas: Cultural and ideological perspectives (pp. 41-122). TelAviv: Am Oved. (Hebrew).

Cantor, A. (1995). Jewish woman/Jewish man: The legacy of Jewish patriarchy. San Francisco: HarperCollins.

Coakley, S. (1997). Religion and the body. Cambridge: Cambridge University Press.

Connell, W. R. (1995). Masculinities. Cambridge: Polity Press.

Cornwall, A., \& Lindisfarne, N. (1994). Dislocating masculinity: Gender, power and anthropology. In A. Cornwall \& N. Lindisfarne (Eds.), Dislocating masculinity: Comparative ethnographies (pp. 11-47). London: Routledge.

Eilberg-Schwartz, H. (1990). The savage in Judaism: An anthropology of Israelite religion and ancient Judaism. Indiana: Indiana University Press.

Eilberg-Schwartz, H. (1992). People of the body: Jews and Judaism from an embodied perspective. Albany, NY: State University of New York Press.

Eilberg-Schwartz, H. (1996). God's phallus and the dilemmas of masculinity. In S. B. Boyd, W. M. Longwood, \& M. W. Muesse (Eds.), Redeeming men: Religion and masculinity (pp. 36-48). Louisville, KY: Westminster John Knox.

Etkes, E. (1982). Rabbi Yisrael Meir Salanter and the beginning of the Musar Movement. Jerusalem: The Zalman Shazar Center for Jewish History. (Hebrew).

Ferree, M., Lorber M. J., \& Hess, B. (1999). Revisioning gender. Thousand Oaks, CA: Sage Publications.

Finkelstein, A. (1997). Preparing Haredi girls for their monthly cycle and sexual maturity. MA dissertation, Hebrew University of Jerusalem. (Hebrew).

Foucault, M. (1977). Discipline and punish: The birth of the prison. New York: Pantheon Books.

Foucault, M. (1978). The history of sexuality. New York: Vintage Books.

Frank, A. (1991). For a sociology of the body: An analytical review. In M. Featherstone, M. Hepworth \& B. S. Turner (Eds.), The body: Social process and cultural theory (pp. 36-102). London: Sage Publications.

Freidman, M. (1991). Haredi Society: Origins, trends and processes. Jerusalem: Jerusalem Institute of Israel Studies. (Hebrew).

Gantsfrid, S. (1989). Kitzur Shulhan Aruch. Jerusalem: Orot Chaim. (Hebrew).

Gilman, S. (1991). The Jew's body. New York: Routledge.

Gluzman, M. (1997). The yearning for heterosexuality: Zionism and sexuality in Altneuland. Theory and Criticism, 11: 145-163. (Hebrew).

Goffman, E. (1961). Asylums. Garden City, NY: Doubleday. 
Goldman, C. B. (1999). Hasidic women's head coverings: A feminized system of Hasidic distinction. In L. B. Arthur (Ed.), Religion, dress and the body (pp. 4661). Oxford: Berg Publishing.

Gutmann, M. C. (1997). Trafficking in men: The anthropology of masculinity. Annual Review of Anthropology, 26: 385-409.

Hakak, Y. (2004). Vocational training for ultra-orthodox men. Jerusalem: Floersheimer Institute for Policy Studies. (Hebrew).

Hakak, Y. (2005). Spirituality versus earthliness in the Lithuanian Yeshivas. Jerusalem: Floersheimer Institute for Policy Studies. (Hebrew).

Horowitz, N. (2002). 'Our town is burning': Ultra-orthodox politics between the elections of 1999 and 2001. Jerusalem: Floersheimer Institute for Policy Studies. (Hebrew).

Jacob, L. (1997). The body in Jewish worship: Three rituals examined. In S. Coakly (Ed.), Religion and the body (pp. 71-90). Cambridge: Cambridge University Press.

Kaplan, D. (1999). David, Yehonatan and other soldiers. Tel Aviv: Ha Kibbutz Hameuhad. (Hebrew).

Katz, D. (1970). The Mussar movement: Its history, leading personalities and doctrines. Jerusalem: Weiss Printers. (Hebrew).

Katz, D. (1996). The grandfather of Slabodka: Rabbi Natan Tsvi Finkel, his life and works. Jerusalem: Feldheim. (Hebrew).

Kirkely, E. A. (1996). Is it manly to be Christian? The debate in Victorian and modern America. In S. B. Boyd, W. M. Longwood, \& M. W. Muesse (Eds.), Redeeming men: Religion and masculinity (pp. 80-88). Louisville, KY: Westminster John Knox Press.

Krondorfer, B. (1996). Introduction. In B. Krondorfer (Ed.), Men's bodies, men's gods: Male identities in a (post-) Christian culture (pp. 3-27). New York: New York University Press.

Krondorfer, B. (2007). Religion and gender: Gender democracy in multi-religious Europe. Transcription of a lecture given at the Heinrich Boell Foundation, Berlin, 13 December 2007.

Leibovitz, Y. (1993). Heroism. In A. Cohen \& P. Mendes-Flor (Eds.), The contemporary Jewish cultural lexicon: Concepts, movements and beliefs (pp. 62-67). Tel Aviv: Am Oved. (Hebrew).

Leoussi, A. S., \& Aberbach, D. (2002). Hellenism and Jewish nationalism: Ambivalence and its ancient roots. Ethnic and Racial Studies, 25(5): 755-777.

Lomsky-Feder, E., \& Rapoport, T. (2003). Juggling models of masculinity: RussianJewish immigrants in the Israeli army. Sociological Inquiry, 73(1): 114-137.

Longhurst, R. (2001). Bodies: Exploring fluid boundaries. London: Routledge.

Lupo, J. (2003). A shift in Haredi society: Vocational training and academic studies. Jerusalem: Floersheimer Institute for Policy Studies. (Hebrew).

Mellor, P. A., \& Shilling, C. (1997). Re-forming the body: Religion, community and modernity. London: Sage Publications.

More, S. D., \& Anderson, J. C. (1998). Taking it like a man: Masculinity in 4 Maccabees. Journal of Biblical Literature, 117(2): 249-273. 
Muesse, M. W. (1996). Religious machismo: Masculinity and fundamentalism. In S. B. Boyd, W. M. Longwood, \& M. W. Muesse (Eds.). Redeeming men: Religion and masculinity (pp. 89-103). Louisville, KY: Westminster John Knox Press.

Nordau, M. (1902). What is the meaning of physical exercise for us, the Jews? In B. Netanyahu (Ed.), Zionist writings, II (pp. 82-87). Jerusalem: The Zionist Library. (Hebrew).

Oryan, S. (1994). Nothing more beautiful than modesty: Communication models in the socialization of Haredi girls. MA dissertation, University of Haifa. (Hebrew).

Ouzgan, L. (2006). Islamic masculinities. London: Zed Books.

Ravitzky, A. (1996). Messianism, Zionism, and Jewish religious radicalism. Chicago: University of Chicago Press.

Sasson-Levi, O. (1998). The image of secularism in Haredi journalism. Ramat Gan: Am Hofshi Publishers. (Hebrew).

Sasson-Levi, O. (2006). Identities in uniform: Masculinities and femininities in the Israeli Army. Jerusalem: Magnus. (Hebrew).

Satlow, M. L. (1996). 'Try to be a man': The rabbinic construction of masculinity. Harvard Theological Review 89(1): 19-41.

Schwartz, Y. (1997). The path to the yeshiva: A preparatory manual for yeshiva study. Jerusalem: The Institute for Furthering Torah Studies. (Hebrew).

Selengut, C. (1994). By Torah alone: Yeshiva fundamentalism in Jewish life. In M. E Marty \& S. Appleby (Eds.), Accounting for fundamentalism: The dynamic character of movements (pp. 236-263). Chicago: Chicago University Press.

Sered, S. (1999). 'Woman' as symbol and women as agents: Gendered religious discourses and practices. In M. Ferree, J. Lorber \& B. B. Hess (Eds.), Revisioning gender (pp. 67-83). Thousand Oaks, CA: Sage Publications.

Shorek, Y. (2002). Body culture in the doctrines of the founders of the Zionist movement. In H. Harif \& H. Kaufman (Eds.), The culture of sport and body in twentieth century Israel (pp. 9-24). Jerusalem: Yad Ben Tsvi Publishers. (Hebrew).

Sion, L. (1997). Masculine images among fighters: Service in the infantry brigades as a rite of passage from youth to adulthood. Jerusalem: Shain Center for Social Science Research. (Hebrew).

Sivan, E. (1991). Enclave culture. Alpayim, 4: 45-98. (Hebrew).

Soucy, A. (1999). Masculinities and Buddhist symbolism in Vietnam. In K. Biber, T. Sear \& D Trudinger (Eds.), Playing the man: New approaches to masculinity (pp. 123-134). Sydney: Pluto Press.

Torevell, D. (1997). Taming the Lion of Judah: Masculinity, the body and contemporary Christian liturgy. Journal of Contemporary Religion, 12(3): 383400.

Turner, B. (1996). The body and society. London: Sage Publications.

Welland, T. (2001). Assaults upon the self: Control and surveillance in a theological college. Journal of Contemporary Religion, 16(1): 71-84.

Weis, M. (2002). The chosen body: The politics of the body in Israeli society. Stanford, CA: Stanford University Press. 
Yaffe, O. (2004). Being a Haredi girl: Socialization practices, pedagogical discourse and construction of the self. Doctoral Dissertation, Hebrew University of Jerusalem. (Hebrew).

Notes

${ }^{1}$ Haredi is the singular for Haredim - the Haredi Jews. The word "hared" in Hebrew means tremble and comes from the book of Isaiah (66:5): "Hear the word of the Lord, you who tremble at His word". I use the Hebrew term "Haredi" (and not Ultra Orthodox) because members of the community use it to characterize themselves, and because it is a broader classification which encompasses not only the Eastern European groups. See, for example, Friedman (1991).

${ }^{2}$ The author would like to thank the reviewers of Journal of Men, Masculinities and Spirituality for their useful comments.

${ }^{3}$ As a rule, yeshiva students receive a deferral from army service for as long as they continue to study in the yeshiva. A similar Haredi army unit was active during the 1960s. It was an initiative of the Tze'irei Agudat Yisrael Youth Movement and was meant to absorb Haredi young men who could not or did not want to continue to study Torah. Following strong internal Haredi criticism the number of new recruits was reduced drastically and the unit was disbanded.

${ }^{4}$ This happens every time the Torah is read, usually once a week but also in other special religious events.

${ }^{5} \mathrm{~A}$ Yeshiva is a Jewish religious seminary for unmarried young men. A Kollel is for married men.

${ }^{6}$ I would like to thank participants in the research for their trust in me, and for their openness and readiness to involve me in their world.

${ }^{7}$ Lithuanian Jews (known in Yiddish and Haredi English as Litvish (adjective) or Litvaks (noun)) are Ashkenazi Jews with roots in the Grand Duchy of Lithuania (present-day Belarus, Lithuania, Latvia and the northeastern Suwałki region of Poland). The characteristically "Lithuanian" approach to Judaism was marked by a concentration on highly intellectual Talmud study and it still characterizes 'Lithuanian yeshivas' today, even if they are located in Israel.

${ }^{8}$ The Likud is a secular party, even if committed to Jewish tradition.

${ }^{9}$ For a discussion of the concept of bravery in Judaism, see Leibovitz (1993).

${ }^{10}$ For a comprehensive anthology of sources on this subject see Breuer (2004, p. 544, n.182).

${ }^{11}$ Haredi rabbis totally reject this historical description. From their point of view, the attitude of Judaism towards the body is permanent and unalterable in its essence.

${ }^{12}$ For more on this issue see Ravitzky (1996, pp. 277-305).

${ }^{13}$ See Gutmann (1997) on this issue.

${ }^{14}$ In order to protect the privacy of my interviewees all names are fictitious.

${ }^{15}$ For a more extensive discussion on this issue see Brown (1999).

${ }^{16}$ Avraham refers to the commandment at the beginning of the Shulhan Aruch "He will arise as a lion in the morning to perform the work of his Creator" (Gantsfrid, 1989, p. 18).

${ }^{17}$ And in the mood of the statement by Rabbi Yehoshua Ben Levi, "No man is free like one involved in Torah" (Avot 86) 
${ }^{18}$ For a review of the historical background of the development of accepted dress norms among Yeshiva students, see Hakak (2005, p. 69).

${ }^{19}$ For more on this issue see Hakak (2005, pp. 69-78).

${ }^{20}$ Although this 'exceptional' dress also follows accepted social conventions of a particular social group.

${ }^{21}$ On the lively internal, critical debate within Haredi society, regarding the diffusion of Western fashion in male dress, see Hakak (2005, p. 76).

${ }^{22}$ See for example the article on Ynet by Jinji Friedman (25.10.04) "Seculars have what to learn from the Haredim".

${ }^{23}$ This is as opposed to other Israeli non-Haredi institutions as well as American yeshivas where sport and especially basketball is much more accepted. For a broad review of the 'body culture' as seen in the rabbinic literature of recent generations see Arend (2002).

${ }^{24}$ For more information on the attitude of Haredi society to involvement in sports, see Hakak (2005, 79-91).

${ }^{25}$ Rabbi Shlomo Volbe and Rabbi Yoel Schwartz are amongst them. For Rabbi Schwarz's attitude to the subject and his fear of community censure, see Schwartz (1997, pp. 15, 107, 127-128).

${ }^{26}$ For more on the historical background of the reservations regarding 'corporal culture' as part of Greek culture see Leoussi and Aberbach (2002).

${ }^{27}$ On this issue see Tamar Rotem, "Sport is their escape from the house, from the children, from the husband" (Haaretz Hebrew newspaper, 11.2.2003).

${ }^{28}$ On this issue, see the article by Avishay ben Chayim, "Living from Sabbath to Sabbath" (Maariv, weekend edition, 26.12.2003) and the article by Alon Hadar, "Black-yellow - the Haredi fans of the Beitar football team" (Kol Ha'ir, 15.12.2000, pp. 74-80.

${ }^{29}$ The Haredi communities, both in the USA and Europe, are much more open to various sports in comparison to the Israeli Haredi community. Many Haredi yeshivas both in the USA and Europe have basketball courts on their premises.

${ }^{30}$ On this issue, see for example, Rabbi Baharan (1990, p. 167), who quotes from the Sefer HaChinuch (Book of Education) regarding the prohibition of revenge and of bearing a grudge: "It is of the roots of the commandment, that a person should know that everything that happens to him has a reason determined by the Holy One, blessed be He... Therefore, when a person is saddened or hurt by someone, he will know in his heart that his transgressions caused it, and that the Holy One decreed this, and he will not let his thoughts stray to take revenge, for the other person is not the cause of the evil..." The proper attitude towards the issue of male assertiveness, especially in situations of conflict, arises anew each year, around the time of Chanukah and the Holocaust Martyrs' and Heroes' Remembrance Day when Haredi newspapers discuss the secular interpretation of bravery and clarify how Haredi Jewry relates to these issues. According to Haredi understanding, while the secular world glorifies physical bravery, Haredi Jewry exalts the bravery of the spirit; while secular nationalism aggrandizes the readiness to die for the homeland, Haredi Jewry sanctifies the name of G-d, dying for it when necessary.

${ }^{31}$ The phrase 'open a distance' is part of the Israeli militaristic jargon and means treating someone in a superior, patronizing and detached and commanding manner. 
${ }^{32}$ Such descriptions were repeated by many interviewees. It seems that these feelings were mitigated following the establishment of the Likud-Shinui government and the 'Netanyahu edicts' imposed when Binyamin Netanyahu served as Minister of Finance in 2003.

${ }^{33}$ Selengut (1994) shows how, since the establishment of the State of Israel, the heads of Lithuanian Yeshivas constantly warned of the penetration of activist types of behavior and belief in the force of arms into the Haredi public. Such warnings were voiced after the Israeli army's victory in the Six Day War and on other occasions. He quotes (p. 245) Rabbi Zvi Elya, who, at an Agudat Yisrael conference in the USA in 1990, rebuked 5,000 people for what he identified as their sympathy for Rabbi Meir Kahane, who was murdered shortly before. Kahane, who coined the slogan, 'Never again', encouraged Jews to react violently to attacks against them. Rabbi Zvi Elya believes that Kahane thereby violated Jewish belief. "Never again", said Rabbi Elya, "Is an anti-Jewish and anti-religious slogan. If G-d wants to bring a Holocaust on us He will do so. 10,000 Kahanes will not stop him."

Yohai Hakak, Senior Lecturer

School of Health Sciences and Social Work, University of Portsmouth James Watson (West), 2 King Richard 1st Road, Portsmouth PO1 2FR/UK e: yohai.hakak@port.ac.uk 